\title{
CARTAS: um exercício de cumplicidade subversiva para a escrita acadêmica
}

\author{
Bruna Moraes Battistelli \\ Universidade Federal do Rio Grande do Sul - UFRGS, Brasil \\ Érika Cecília Soares Oliveira \\ Universidade Federal Fluminense - UFF, Brasil
}

\begin{abstract}
Resumo
Qual sua experiência com a escrita de cartas? Você já escreveu uma para alguém? Apostando na potência destas, já não somos apenas pesquisadoras, mas também, escrevedoras de cartas e carteiras. Assumimos desta forma, uma escrita que flerta com a oralidade, de modo que uma carta funciona como um escrever falando. Assim, habitamos uma escrita de fronteira entre oralidade e grafia para fazer furo na escrita acadêmica hegemônica. Para tanto, tomamos a escrita pessoal como um exercício político, e a partir de nossas diferentes experiências propomos um exercício de cumplicidade subversiva para apresentar uma outra performance de escrita acadêmica através das cartas. Uma escrita para desobedecer e esperançar que permite um esticamento da voz e um alargamento do tempo em uma relação de artesania dos encontros. Trocar cartas, então, articula um pesquisar que se dá pela escrita e pela conversa, em uma política de pesquisa que se abre à multiplicidade de vozes e experiências.
\end{abstract}

Palavras-chave: Cartas; Escrita; Língua; Política de escrita.

\begin{abstract}
What is your experience with letter writing? Have you ever written to anyone? Betting on the potency of the letters, we are no longer just researchers, but also letter writers and postwomen. In this way, we adopt a kind of writing that flirts with orality, so that a letter works like a writing that speaks. Thus, we inhabit a writing on the border between orality and spelling to make a hole in the hegemonic academic writing. Therefore, we take the personal writing as a political exercise, and from our different experiences we propose an exercise of subversive complicity to show another academic writing performance by means of letters. A writing for disobedience and hope that permits a voice stretching and a time enlargement in a relation of meetings artisanship. Therefore, exchanging letters articulates a research that occurs through writing and conversation, in a research policy open to the multiplicity of voices and experiences.
\end{abstract}

Keywords: Letters; Writing; Language; Research policy. 


\section{Carta 1 - Para minha avó}

Olá Vó,

Como está? Espero que estejas bem! Depois de anos te escrevo novamente. Não são mais aquelas cartas de quando eu era adolescente em que transcrevia o que a mãe queria dizer. Te escrevo porque quero contar o que ando fazendo e em como levei seu conselho a sério: tu me dizias para estudar, pra não depender de ninguém e cá estou no doutorado. A mãe sempre fala como se eu não tivesse saído da escola, pois volta e meia ela pergunta como está o colégio. Eu queria que a senhora pudesse ter ido nas minhas formaturas e visse o tanto de diploma que tenho. Senti sua falta em cada uma delas. Eu acho que a senhora ia gostar (não ia expressar isso), ia ser daquele seu jeito meio duro de ser e que se sentia desconfortável quando o abraço demorava demais.

A mãe e o pai lhe mandam abraços. A senhora não tem ideia do mundo de coisas que já nos aconteceu. E de como a mãe e as tias tão cada vez mais parecidas com a senhora (suas manias as acompanham). Sinto saudade suas e do vô, um dia ainda vou escrever sobre como aprendi com vocês. Sem me espichar demais, queria dizer que hoje trabalho com cartas, escrita, cuidado e sou psicóloga e gosto muito de pensar formas para nos escutarmos e podermos conversar. Inventei uma coisa que chamo de cartagrafia, que é mais ou menos uma história de pesquisar com as pessoas por meio de cartas e ir escrevendo-as como forma de contar o que penso, o que produzo na universidade. Uma forma de conversar que envolve se corresponder por escrito. Aprendi com a senhora e com a mãe que burlavam a distância usando os correios, já que não tínhamos outra forma de ter notícias suas e do vô.

Tenho recebido reconhecimento com meu trabalho e espero que logo eu consiga um emprego em decorrência dele, sonho em ser professora. A mãe queria que eu fosse professora de crianças, mas isso não se concretizou. Infelizmente para algumas pessoas eu sempre serei a filha da empregada doméstica, aquela que no imaginário da classe média/alta branca tem um lugar específico a ocupar. Esse sempre foi um sentimento que me acompanhou sendo aluna em uma universidade federal, de que ali não era o meu lugar, que me faltavam habilidades para estar ali. Vó, eu estudei sempre no mesmo lugar (graduação, especialização, mestrado e doutorado). A mãe, no início tinha receio que eu falasse sobre a profissão dela para professoras e colegas e, assim como ela, eu aprendi a dar ouvidos a esse receio. A mãe, ainda hoje, às vezes inventa um nome para a profissão de vocês dependendo da situação e lugar (nem lembro como ela fala do trabalho, mas costuma ser de uma forma a escapar do preconceito dos outros). Estar na graduação e pós-graduação sempre foi uma experiência envolta de sentimentos confusos/ambíguos, eu sentia como se estivesse sempre com um pé dentro e outro fora. Preciso te contar: quando fui aprovada no doutorado a filha do patrão da mãe ligou para ela sugerindo que tinha um conselho para mim, que era preocupação da parte dela. Um conselho que recomendava que eu não abandonasse meu trabalho como servidora pública, em um município do interior do estado para assumir uma bolsa no doutorado. Ela se dizia preocupada comigo e com a oportunidade que eu estaria abandonando. Essa história me incomodou profundamente, pois trouxe de volta a ideia de que eu era um corpo que não cabia na universidade pública. Lembrei de todas às vezes que as professoras do Magistério diziam 
que a UFRGS não era para nós, que não precisávamos estudar para o vestibular. Mas foi bom isso ter acontecido, pois me ajudou a fazer algo que até então eu tinha muitas dificuldades em fazer: localizar meu conhecimento, localizar meu corpo e minhas experiências. E vó, depois disso eu passei a contar a minha experiência em todos os lugares. E a escrever sobre ela sem ter vergonha e entender que essa é construída.

Um resquício desse sentimento é a sensação de que não sei escrever da forma que a universidade pede/exige e de que estou sempre fazendo as coisas de uma maneira que não é certa. Isso é ruim vó, porque gosto muito de pesquisar, escrever e pensar. Mas quando me boto a escrever, parece sempre que sou inadequada a esse mundo, sempre como se estivesse com um pé fora e o outro dentro. Mas tenho lidado com isso e feito disso matéria das minhas pesquisas. Assim, tenho me enchido de coragem com o que as pessoas falam da forma como sigo pesquisando e escrevendo o que penso do jeito que acredito. E defendendo isso, vó! Coisa que aprendi com mulheres como tu, a mãe, as tias. Enfim, para não me alongar muito, eu espero que o universo esteja cuidando bem da senhora e do vô.

Um abraço, sua neta!

\section{Carta 2 - Olhar para trás}

Mãe,

Cresci com você dizendo que um dia escreveria um livro cujo título você já havia criado: O professor, esse incógnito. Você dizia o nome do livro assim mesmo, no masculino. Não poderia ser diferente. Eram os anos de 1980 e demoraria muito para que se pulverizasse a ideia de que a linguagem sexista apagava todas as mulheres. Justo nós que já éramos apagadas de tantas outras esferas da vida. Seu livro nunca foi escrito e você sempre permaneceu uma desconhecida. Aposentou-se do magistério precocemente, por questões emocionais (ninguém teria escrito em algum laudo que você se aposentava devido aos excessos das violências patriarcais sofridas em sua própria casa). Profissionalmente, você enterrava sua carreira e emocionalmente, você se afastava de mim e do meu irmão. Pior que tudo, você se afastava de si mesma, da moça que dava presentes para os sobrinhos, como costumava me contar uma prima, querendo me explicar quem foi você, já que talvez eu nunca tenha tido a oportunidade de conhecê-la realmente. Você se transformava numa pessoa descolada da realidade, inutilizada para o mundo que seguia correndo, sem esperá-la.

Durante algum tempo fiquei me perguntando o que você teria dito das professoras, de suas invisibilidades, caso pudesse ter dito algo e se você teria ligado isso ao fato de que as mulheres dificilmente poderiam aparecer, sobretudo naquela época. Não acredito que você tivesse feito algum tipo de correlação, não havia chão histórico no qual você pudesse assentar suas histórias, derramar suas lágrimas. Tudo era silêncio.

Em meu imaginário ficaram sobrevoando os fantasmas das suas palavras que não puderam habitar o mundo. Mesmo não podendo colocá-las para fora, você foi generosa e presenteou-me com uma máquina de datilografar quando eu tinha 14 anos, ocasião em que fazia um curso de datilografia para poder participar de alguns minguados concursos de 
literatura que eram divulgados esporadicamente em algum jornal local. Eu carrego até hoje essa máquina comigo. Nessa época, eu devorava livros de literatura que emprestava da biblioteca municipal, tentando tapar a solidão que a nossa separação havia produzido em mim. Mergulhava nos livros e escrevia intensamente em cadernos que depois foram jogados fora, que nunca mais pude ver, um amontoado de palavras na tentativa febril de colocar ordem nas emoções, nos pensamentos e no próprio desespero. Passei uma vida inteira tentando compreender tudo o que havia acontecido com você e até hoje me vejo montando as peças deste quebra-cabeça cuja figura final é a ficção de que mulheres foram feitas para obedecer, silenciar, seguir em frente e fingir que nada aconteceu.

Ao longo dos anos, fui abandonando a escrita e somente no doutorado resolvi que só poderia pesquisar se recuperasse esse gesto. Parecia que somente faria sentido estar na universidade, se pudesse trazer algo da minha casa junto. Hoje em dia, diferente de você, escrevo muito sobre aspectos da minha profissão, sei que não precisarei abandonar a minha carreira e posso me colar à realidade por mais sufocante que às vezes ela possa parecer. Talvez sem nos darmos conta, você tenha me mostrado a importância de colocar em palavras aquilo que experienciamos. Eu demoraria muito para compreender o significado da palavra incógnito, afinal era apenas uma criança, como demoraria também para saber que você foi uma ponte que pude atravessar para chegar deste lado. Você, como muitas mulheres da sua geração, criara as oportunidades para que nós, suas filhas, pudéssemos falar.

Com carinho, sua filha.

\section{Por que cartas?}

Cartas não existirão mais? Palpáveis, escritas no papel, seladas e impregnadas de significados emocionais agregados a elas pelo ato de enviá-las ou de recebê-las, sentir o seu peso, volume, cheiro e a surpresa de abri-las e desdobrá-las... Essas serão raridade. Na verdade, não aguardamos mais por elas e perdemos o hábito de escrevê-las. Mas, talvez, ainda possamos ser surpreendidos [...] com o recebimento de uma carta de cunho pessoal, amigável e afetiva (ARAÚJO, 2016, p. 76).

Qual sua primeira experiência com cartas e correio? Você já escreveu uma para alguém? Ou as correspondências que recebe são as publicitárias e de cobrança? Visitando sua caixa de correio: o que encontraremos?

Perguntas que nos acompanham. Algumas experiências prévias nos auxiliam como a dissertação da primeira autora nominada "Carta-grafias: entre cuidado, pesquisa e acolhimento" que inicia o interesse por cartas que posteriormente aproxima a segunda autora. A pesquisa que culminou com a dissertação foi uma primeira experiência com a instalação de um correio que durou três meses e aconteceu em um serviço de acolhimento institucional $^{2}$ para crianças e adolescentes em Porto Alegre. A pesquisa tinha como objetivo analisar como se constituíam as práticas de cuidado no acolhimento institucional de crianças e adolescentes no município de Porto Alegre; e cuidado aqui deve ser entendido como acontecimento (MERHY 2013), como aquilo que acontece no espaço intercessor entre 
sujeitos nos encontros da pesquisa. $\mathrm{O}$ procedimento consistia em frequentar o serviço e levar cartas para as pessoas envolvidas, com o foco inicial nas/nos trabalhadoras/trabalhadores, mas $\operatorname{logo}$ as crianças e adolescentes se interessaram pelo processo e passaram a ser destinatárias também. Um correio instalado desta forma não necessariamente está preocupado com as respostas que virão e sim com os encontros que serão acionados. Não há interesse em contabilizar respostas escritas, mas sim que as cartas sejam meios de acionamento de uma teia de cuidado que se dá pela escrita, por conversas e por compartilhamento de afetos. Junto a estes procedimentos o interesse pela fabricação de objetos surge como consequência do processo de compartilhamento de escritas.

Quando se escreve e se recebe cartas é preciso guardá-las de alguma forma: caixas, sacolas e tudo mais que possa ser usado para compartilhar e cuidar delas passam a ser foco de preocupação da pesquisadora-carteira. Afinal, como guardamos nossas recordações, nossas escritas afetuosas e presentes que ganhamos? Ana Cristina César $^{3}$ foi a primeira inspiração, quando disse em uma carta de 5 de abril de 1976 que consta no livro "Correspondência Incompleta": "Planejo um baú (ou um arquivo, pra ser moderna) com bolinhos de envelopes amarrados com fitas azuis e vermelhas" (CÉSAR, 1999, p. 16). Ana Cristina César foi a guia-colecionadora na pesquisa de mestrado que estamos narrando. Anteriormente ao livro citado, conhecer a obra "Antigos e soltos: poemas e prosas da pasta rosa" (2008) que reúne escritos da autora impulsionou a curiosidade sobre os efeitos que objetos fabricados produziriam em intervenções da psicologia. A publicação é o testemunho do processo criativo da escritora, que se tornou ícone da poesia marginal nos anos 1970/1980, e apresenta textos de diversos gêneros: poemas, fragmentos de diário, anotações íntimas em cadernos de aula, relatos de viagem, bilhetes e cartas nunca enviadas. $O$ material foi preservado pela mãe da poeta, Maria Luiza, e doado pela família ao Instituto Moreira Salles (IMS), onde se encontram todos seus originais. Posteriormente, este material foi catalogado por Manoela Daudt de Oliveira e reorganizado por Viviana Bosi.

Deste modo, junta-se a isso o interesse pelas cartas pessoais onde trocam-se com as/os destinatárias/os textos, afetos, planos, sonhos, e tudo mais que couber em uma conversa que se efetiva num tempo outro (no tempo alargado entre a escrita, a entrega e a possível resposta). Uma conversa com potencial para seguir de forma infinita dependendo da relação que se estabelece entre as pessoas envolvidas. Qual o efeito de uma carta escrita à mão? Desta forma, instalar correios (fictícios ou reais) se constitui como estratégia de produção de intervenções que encantem a Psicologia a partir de uma ética da polinização de afetos (ROLNIK, 2018), pensando que com o ato de trocar correspondências podemos polinizar gérmens de futuro, como afirma a autora.

Outros trabalhos desdobram-se a partir deste processo: "Cartas à Assistência Social" (BATTISTELLI; CRUZ, 2019a), um capítulo de livro escrito na forma de uma coleção de cartas com a intenção de discutir o trabalho da Psicologia no campo da Assistência Social. "Branquitude I" e "Branquitude II" (BATTISTELLI, [2020a], [2020b], no prelo) verbetes escritos em formas de carta para livro sobre juventudes e que discutem o tema da branquitude na universidade. "Cartas sobre cuidado" (CATANIO; BATTISTELLI, 2019), um artigo formado por cartas de uma residente em saúde mental pensando o tema do cuidado. "Entre 
cartas: sobre a branquitude e epistemicídio na produção de conhecimento em Psicologia" (RODRIGUES, L.; BATTISTELLI, [2020], no prelo), capítulo formado por uma troca de cartas entre as autoras para discutir a branquitude e os apagamentos que esta produz na produção de conhecimento em Psicologia e "Manifesto Antirracista: carta a Sara Baartman" (OLIVEIRA, 2020), uma carta enviada à sul-africana Sara Baartman a fim de falar sobre os privilégios epistêmicos e injustiças cognitivas que assombram as universidades brasileiras, excluindo teorizações de autoria negra.

Portanto, nosso interesse se dá por correios que se espalhem na perspectiva de cultivar encontros e promover aberturas. O poder de envelopes lacrados e pintados é o de abrir mundos com seu conteúdo e principalmente por conta de seu endereçamento, em uma escrita que conhece a/o destinatária/o. Logo, ocupar-se com instalações de correios, escritas de cartas e polinização de afetos é promover uma escrita que necessita de suas/seus destinatárias/os para fazer sentido. Desta forma, a/o pesquisadora/pesquisador que assume um fazer cartagráfico está implicada/o com uma produção que visa dialogar sobre escrita, pesquisa e cuidado, preocupada/o em performar uma metodologia que consiga acionar encontros e escritas que façam a vida vibrar e que acione diferentes modalidades textuais. Nomear como cartagrafia, desta forma, diz respeito à importância que ganham as correspondências no processo de pesquisa. Uma política de pesquisa inspirada em metodologias como pesquisa-ação, cartografia e pesquisar com.

Mas como uma dissertação ou tese pode ser produzida desta forma? Com quais objetos nos acostumamos no mundo acadêmico da Psicologia? O que pactuamos como objetos aceitáveis quando da entrega de teses e dissertações? Um arquivo em pdf? Um bolo de folhas impressas e encadernadas? Poderia uma dissertação ter formato de caixa? Um projeto de qualificação ter formato de sacolas? Como instalar um correio de troca de correspondências sem uma caixa de correios? Trazemos estas questões que nos acompanham como introdução para as pistas que iremos apresentar: como instalar um correio como intervenção de pesquisa, a escrita de cartas como desobediência e esperança e a possibilidade de descolonização da pesquisa e da escrita a partir das cartas; uma escrita que convida a oralização do texto embasada pela obra de autoras feministas e decoloniais.

\section{Como instalar um correio?}

Seriam os correios uma tecnologia ultrapassada? A tese de Tânia de Castro Araújo (2016) afirma a potência narrativa de caixas de correio, ao mesmo tempo em que relata o esvaziamento delas. A autora aponta que a partir das caixas de correio podemos pensar como nos relacionamos com as mídias, trocas de mensagens e correspondências digitais, assim como problematizarmos a relação com as memórias na contemporaneidade. Evocar um objeto como a caixa de correios em uma pesquisa é respeitar sua dimensão de lugar de passagem, entrada e acúmulo de memórias (ARAÚJO, 2016).

Portanto, um procedimento importante em um processo cartagráfico é a instalação de um correio; uma sistemática que envolve escrita, entrega e recebimento de cartas. Mas o que 
são estas? Pode ser qualquer coisa que possa ser encaminhada pelos correios (aqui falando da instituição Correios). Acionamos a memória de uma escrita pessoal, afetiva e manuscrita, estabelecendo uma relação de artesania com o escrever. Desta maneira, o procedimento da cartagrafia tem em vista que a pesquisadora irá ocupar o papel de escrevedora e leitora de cartas bem como de carteira.

De forma similar há uma artista que produz sua obra e tem de antemão alguns efeitos que quer produzir nas pessoas, um correio trabalha com a intenção de produzir diálogos, proporcionar o alongamento de um tempo mediado pela troca. Compartilha-se a pesquisa em si, os procedimentos, os sentimentos envolvidos, as dúvidas, preocupações, indagações e abre-se ao correspondente a possibilidade de seguir a conversa ou não. Pesquisadora e pesquisa, desta forma, desnudam-se como parte do processo, permitindo que as/os participantes possam produzir suas indagações. Troca-se com papéis, com envelopes, mas também com conversas, com desenhos, com silêncios. Instalar correios é produzir tempo. Não o da rapidez das mensagens ligeiras, dos e-mails, das ligações do telefone e das redes sociais. Isto posto, um dos objetivos da pesquisa é permitir alongamentos; e como alongar um encontro? Acreditamos que encontramos uma pista no que aponta Flusser (2010) ao afirmar que se houvesse uma filosofia desenvolvida por troca de correspondências, ela deveria partir de uma análise do esperar. De acordo com ele, "cartas são coisas por que se espera - ou que chegam inesperadamente" (Flusser, 2010, p. 116). Em meio às turbulências com as quais nos encontramos, não seria um exercício importante apostar em uma escrita que nos exige exposição, que nos exige paciência e que tem "o poder mágico de máquina do tempo" (RODRIGUES, S., 2017, p. 8)? Uma política do Texto com uma relação íntima com o tempo. "A lentidão era o habitat dos missivistas", diz Sérgio Rodrigues (2017, p. 8).

Quem se propuser a instalar um correio precisa se preparar, pois precisará escrever muitas cartas, expor-se a cada uma delas e aceitar o inesperado como resposta. Precisará também estar presente. Não há chance que um correio se instale sem a presença da pesquisadora/carteira. Uma das premissas de uma pesquisa como a que estamos propondo é o ativo exercício do corpo da pesquisadora. É preciso se dispor corporalmente neste processo. Desta forma as pessoas, destinatárias deste correio, só se disporão ao encontro sabendo que é recíproco da parte de quem propõe este desafio.

Para instalar um correio é preciso uma relação com a Arte Postal, movimento artístico que tem seu início nos anos de 1960 e constituía-se por redes de comunicação entre artistas que produziam trocas de trabalhos e materiais por meio dos correios. Schedler (2016) afirma que um dos intuitos da Arte Postal (fazer arte) só se completava quando estava em uma relação de trânsito. Nesta época, as experiências com Arte Postal foram as mais diversas no mundo. O coletivo internacional de artistas intitulado Fluxus organizou uma série de performances entre os anos de 1960-1970, tendo sua produção com interesse pelo cotidiano e defendendo a ideia da circulação de trabalhos de forma democrática e o mais próximo possível ao público (SCHEDLER, 2016). Um dos impactos importantes do movimento é uma dupla crítica ao sistema hegemônico das artes: fazer uso dos correios como modo de troca e compartilhamento, e estabelecer proposições que os museus não reconheceriam como tendo o status de obra de arte. A vivência do instante e o envolvimento do espectador com o 
material é ponto central no trabalho, o que permite que a obra ganhe status de arte (SOUZA, L., 2010).

No Brasil, assim como na América Latina, a Arte Postal ganha força e visibilidade nos anos de ditadura, sendo muito utilizada pelos artistas para driblar o sistema repressor que se instaurou desde a década de 1960. Paulo Bruscky é um dos artistas brasileiros mais proeminentes deste movimento, pautando sua produção pela premissa de que a obra de arte está sempre em movimento e de que a mensagem é fundamental para que se consolide o status de obra de arte. Por conseguinte, diferentemente de outras experiências no mundo, a Arte Postal no Brasil e América Latina tinha também o caráter de denúncia dos anos de violência e repressão vividos nas ditaduras, de modo que atuava de forma subversiva neste cenário. Araújo (2016) afirma que as experiências europeia e estadunidense tinham como foco situar um posicionamento contrário ao sistema instituído do mundo das artes e já na América Latina e Leste Europeu, os movimentos de Arte Postal se caracterizavam pela troca e circulação de informações, devido ao enfrentamento às ditaduras militares e socialistas respectivamente.

Deste modo, aprendemos com este movimento artístico a estabelecer uma relação com os objetos, uma espécie de amizade com envelopes, folhas, canetas, papéis e uma preocupação com as mensagens e com a forma delas, que têm como objetivo um exercício de permitir-se seguir à espreita dos encontros. Para nós, colocar-se nesta posição é estabelecer uma relação de artesania com a pesquisa, como se ela fosse uma atividade manual que nos exige tempo, paciência e um gosto pela espera. E a prestar atenção à relação obra e público envolvido, já que é deste encontro que o movimento se instaura, como também a entender que o correio funciona como suporte que possibilitará o trânsito dos meios (papéis, envelopes, palavras, desenhos). Desta forma, Leonilia Souza (2010) afirma que a Arte Postal foi um dos primeiros movimentos artísticos a propor trabalhos em rede, movimentando trocas e envolvendo pessoas do mundo todo. A autora também relata que um trabalho de Arte Postal não se sustenta sem palavras, desenhos, papeis, plásticos, além de apresentar as diversas formas como o correio influencia nas obras propostas. A/O artista, desta forma, mesmo conhecendo o funcionamento dos correios não tem controle de como este afetará sua criação.

Assim, a Arte Postal serve de inspiração que nos ajuda a propor uma pesquisa em rede, articulável a partir dos encontros possíveis entre as/os interlocutoras/es. O tempo da escrita, entrega das correspondências, os envelopes desenhados e pintados, os tempos peculiares dos correios são parte do que chamamos de cartagrafia. Um certo modo de pesquisar preocupado com a circulação de informações, com o compartilhamento e com o diálogo, em consonância com o que sustenta o movimento da Arte Postal. Para facilitar a visualização do que expomos, a seguir encontram-se duas fotos de correios e objetos recentes que foram produzidos no contexto de pesquisas desenvolvidas no âmbito da Psicologia. A primeira imagem é de um dos correios instalados durante pesquisa de mestrado de uma das autoras (BATTISTELLI, 2017) e a segunda imagem é da sacola-projeto-de-qualificação-de-doutorado ${ }^{4}$ antes de ser enviada para os membros da banca. 
Figura 1 - Instalação de um correio na pesquisa

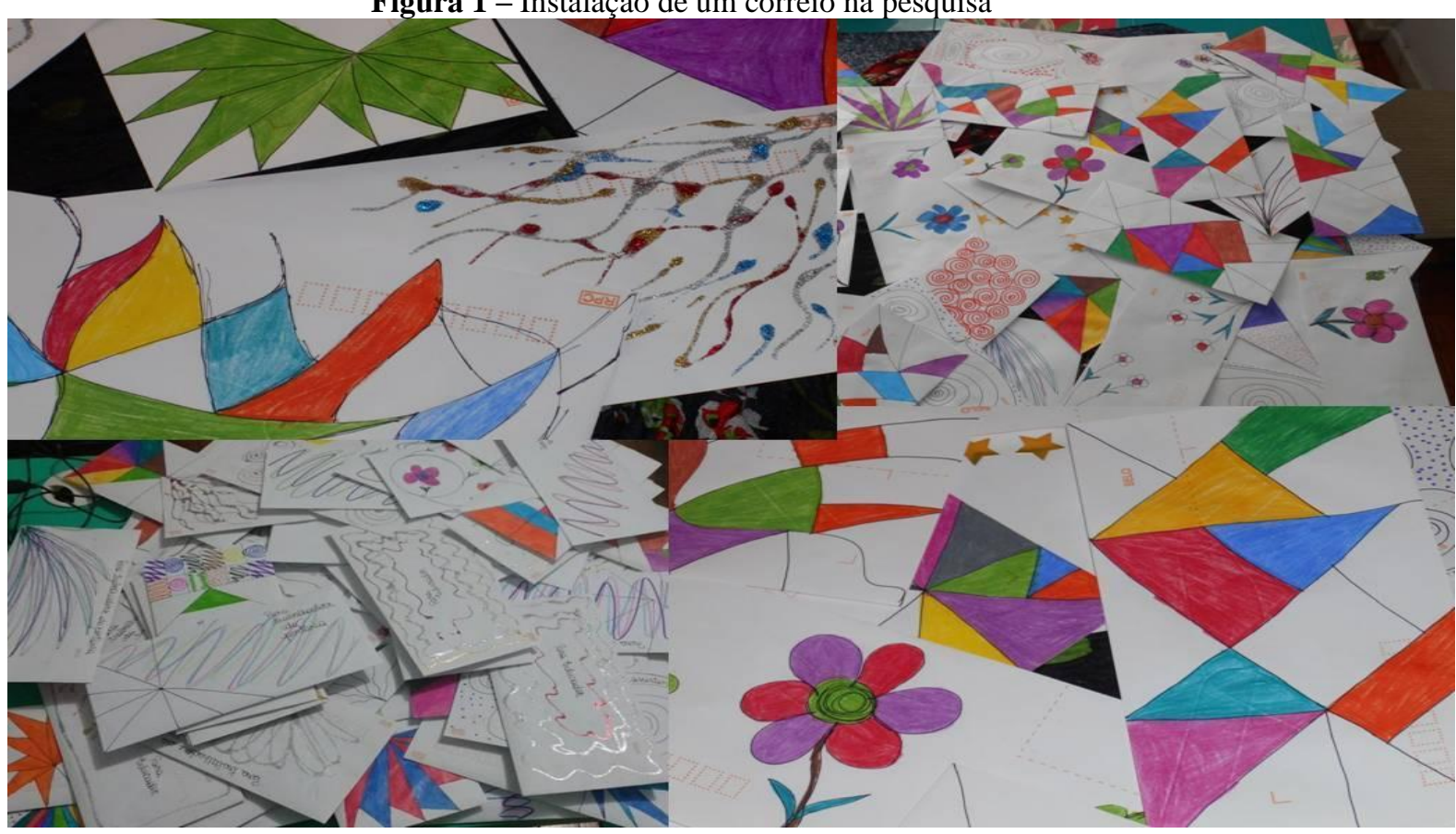

Fonte: Acervo pessoal da autora.

Figura 2 - Sacola-projeto-de-tese

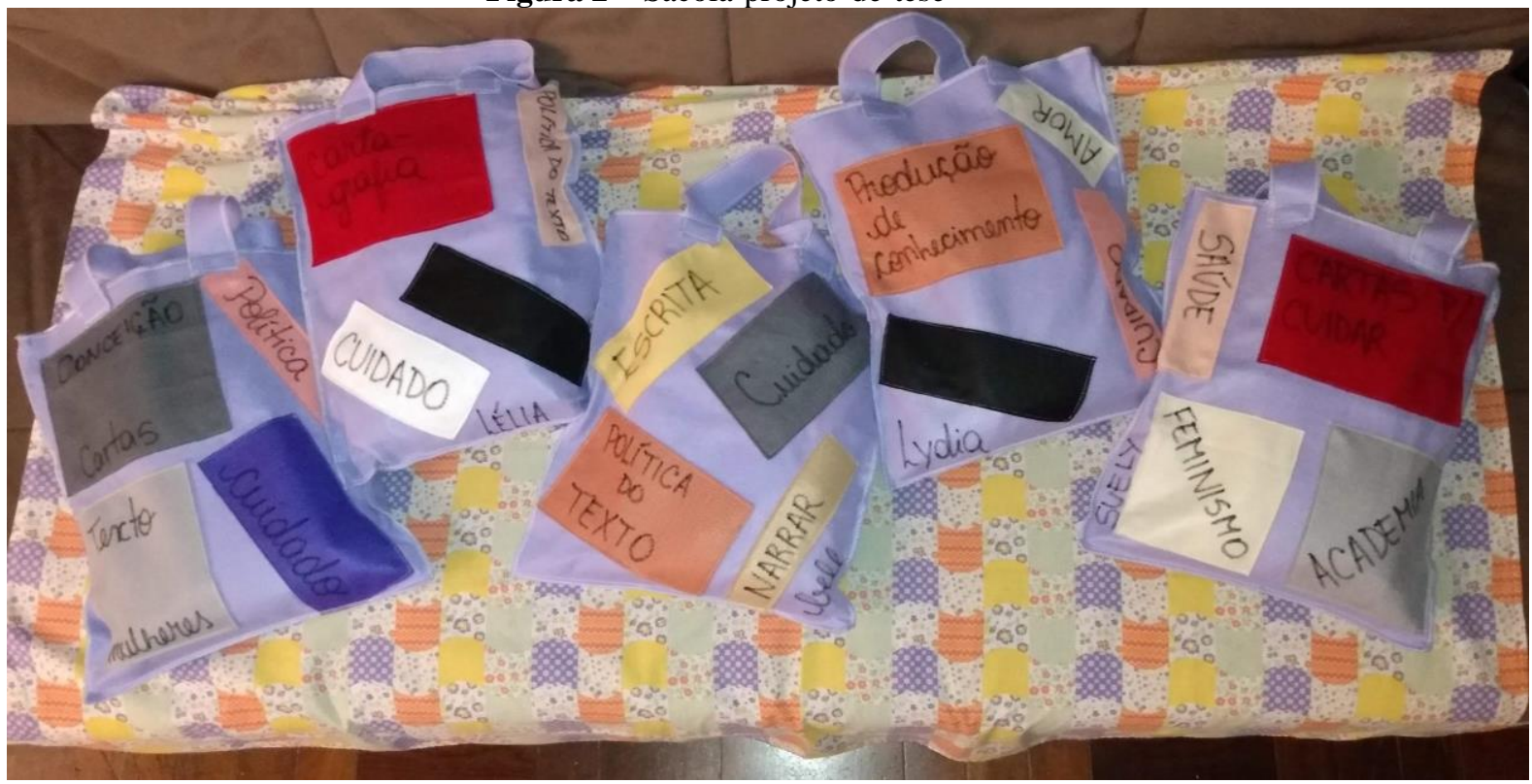

Fonte: Acervo pessoal da autora

A caixa-dissertação tinha como objetivo acolher as muitas histórias que foram ofertadas durante o processo de pesquisa. Como cuidar da escrita que nos é endereçada em uma 
pesquisa? Desde o instante em que a pesquisadora adentrou no serviço de acolhimento institucional de crianças e adolescentes, a preocupação primeira era de que pesquisa e pesquisadora não fossem desconhecidas das pessoas que frequentavam o cotidiano do abrigo. A primeira grande remessa que envolvia aproximadamente 50 missivas que contavam sobre a pesquisa, apresentava a pesquisadora e como ela entendia o estar no abrigo, a pesquisa, explicava os procedimentos éticos e a possibilidade de cada pessoa poder conversar e manifestar seu desejo ou não em participar. A forma como as cartas foram escritas variava conforme os destinatários (adultos, crianças e adolescentes). Para as crianças e adolescentes foram lidas em grupos por uma/um das/dos educadoras/es. Sobre essas relações, uma pequena-carta-e-mail escrita por uma trabalhadora do abrigo chegou ao final da pesquisa:

Bom, em primeiro lugar, queria dizer que adorei a tua iniciativa das cartas. Apresentar-se para a equipe e as crianças, dizer de onde vem e o que pretende, foi de um cuidado e uma delicadeza que me encantaram. Vou treinar um pouco mais de caligrafia e te mando uma carta física qualquer dia desses, ok? (BATTISTELLI, 2017, p. 60).

Os primeiros efeitos que esse correio causou foi que ao chegar no abrigo na outra semana a pesquisadora já era conhecida como a "moça das cartas". Uma adolescente solicitou que a ajudasse a escrever uma carta ao juiz, afirmava que sua audiência estava próxima e ela queria explicar para ele sobre sua situação. Alguns profissionais questionaram sobre a necessidade ou não de responder as cartas que foram entregues e se elas seriam sempre iguais como a primeira. Os desdobramentos, semana a semana, variavam conforme o correio instalado se consolidava e a expectativa criada era para quem seriam enviadas cartas naquela semana.

Com o tempo, quando as crianças e adolescentes indagaram se eles também não participariam da pesquisa, foi necessário repensar os procedimentos. Como o público do abrigo, uma casa de passagem, variava muito de semana a semana, adolescentes e crianças novos eram frequentes e influenciados por outras/os moradoras/es, esperavam uma carta. Como escrever para quem você nem sabia que estava esperando uma carta sua? Com quem você não tinha nem conversado? Deste modo, toda semana algumas cartas sem destinatárias/os eram escritas, na tentativa de atender às expectativas de um público ávido por encontrar um envelope com seu nome. Quando algumas crianças solicitaram que a pesquisadora escrevesse cartas para parentes próximos duas exigências eram postas: ter o nome do destinatário no envelope e que este fosse pintado como os que a pesquisadora distribuía no abrigo. O envolvimento das crianças na pesquisa é narrado no capítulo "Pesquisando com crianças em Acolhimento Institucional" (BATTISTELLI; CRUZ, 2019b). Abaixo, segue a imagem de uma carta que permaneceu no bolso de um educador por dias (nas palavras dele) e que fora escrita por um adolescente. Uma carta inesperada, bem apertada em um envelope dobrado várias vezes. Uma composição que contava com um envelope pintado pelo adolescente, uma florzinha minúscula de plástico e um desenho de coração. 
Figura 3 - Uma carta para a carteira

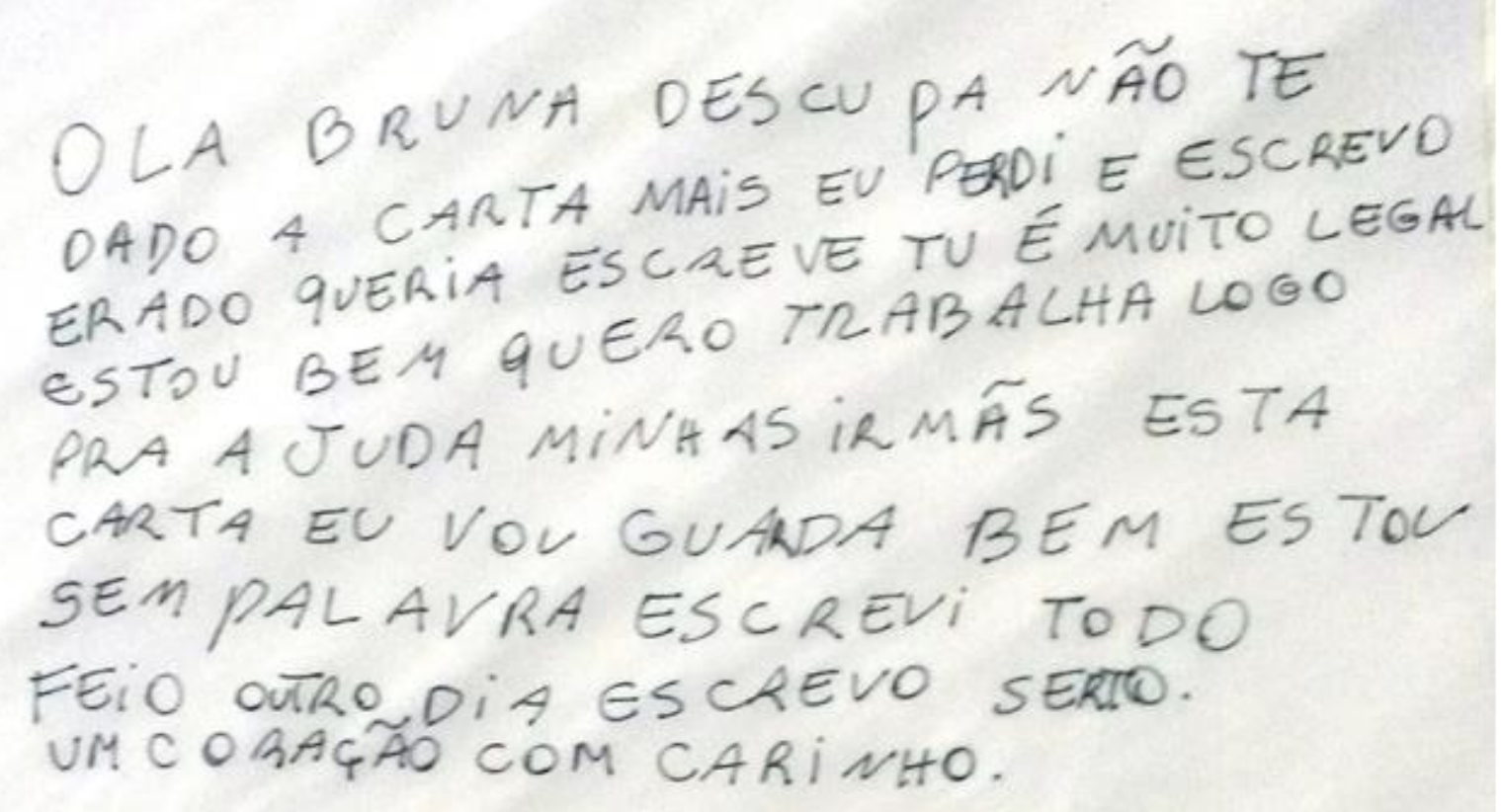

Fonte: Adaptado de Battistelli (2017, p. 118).

Já com os adultos (trabalhadoras e trabalhadores) a relação se dava mediada pela troca de correspondências e pela conversa. Se em uma semana a pesquisadora conversava com alguém, na próxima uma carta era produzida a partir das reverberações do encontro que tinha se dado. A surpresa, principalmente por parte das/dos educadoras/es se dava por uma sensação de que a pesquisadora tinha prestado atenção ao que tinha sido conversado ou observado da rotina. De muitas formas, as seguintes perguntas voltavam à tona: por que estudar um abrigo? O que nós podemos ter de interessante? Por que você quer estudar cuidado em um abrigo? Outra indagação que sempre voltava era também quanto ao tempo gasto com os envelopes. Os envelopes coloridos eram pauta frequente das conversas.

Mas também chegavam notícias de trabalhadoras/es que desconfiavam das cartas, que tinham receio de escrever, por não sentir confiança no trabalho que seria feito com as respostas. A fragilidade dos vínculos empregatícios, em um ambiente como o que serviu de campo para a pesquisa precisou ser pensada, tendo em vista o receio de algumas trabalhadoras. Com algumas/alguns trabalhadoras/es foi possível discutirmos sobre a quebra do anonimato, e desta forma, elas/eles tiveram sua autoria garantida. Essa era uma das reivindicações discutidas desde o início: como seria respeitada a produção de conhecimento das/dos trabalhadoras/es do serviço? Uma das preocupações que tinham era de que muitas pesquisas passavam por ali e pouco retornava ao abrigo quanto ao reconhecimento da produção das/dos trabalhadoras/es. Abaixo segue o início de uma carta anônima que foi endereçada à pesquisadora nas primeiras semanas de observação no ambiente do abrigo: 
O escrutínio que as pessoas que vem pesquisar fazem dos processos de trabalho me lembram pesquisadores que pegam borboletas e as apresentam, mortas, para quem nunca viu uma voar e ficam descrevendo os erros e acertos daquela casca oca.

O quanto a academia é pesada? O quanto a gente aceita seu discurso de mestre? O quanto somos esvaziados do poder criativo em ato e dissecados, catalogados, presos por um alfinete e abandonados ao fazer, que é menos que o pensar? $\mathrm{O}$ quanto estamos divididos entre pensar e agir.

Assim, por melhor que seja o pesquisador, por mais mirabolante que seja seu método, por mais ética que seja sua inserção, por mais respeitoso que seja seu posicionamento, mesmo assim ele não é parte, não faz parte e talvez possa vir a tomar parte, mas e ai algo do seu desejável "distanciamento", sua "isenção" e outras questões metodológicas, se perdem.

As devoluções que são oferecidas pelos pesquisadores não chegam nem perto das miçangas que recebem os nativos. Com as miçangas é possível transformar, criar, deslizar. Mas com a devolução... O que está sendo devolvido? (BATTISTELLI, 2017, p. 32).

Uma pesquisa que trabalhe com cartas, que instigue a participação das/dos envolvidas/os e que faça convites para que as pessoas escrevam precisa estar atenta a como irá acolher as histórias que lhe forem ofertadas. Desta forma, a produção de objetos finais (dissertações e teses) precisa demonstrar o valor que as histórias ofertadas têm para a/o pesquisadora/pesquisador acadêmica/o. A primeira experiência com a cartagrafia apontou que quando entendemos as/os interlocutoras/es como pesquisadoras do seu próprio cotidiano colocamos a pesquisa em constante problematização e a reconstruímos com as pessoas envolvidas. Então, produzir um objeto final, que comportasse as histórias e desenhos ofertados no percurso, se pautou pela tentativa de reproduzir a sensação que o saco de cartas carregado pela pesquisadora produzia no abrigo.

A sacola-projeto-de-qualificação, por sua vez, surge como meio de envelopar uma produção de correspondências que nunca foi entregue para as destinatárias. Eram cartas destinadas para mulheres que influenciaram o processo de pesquisa, intelectuais como bell hooks, Suely Rolnik, Lélia Gonzalez, Conceição Evaristo, Lydia Francisconi, Silvia Cusicanqui, Gloria Anzaldúa. Algumas vivas, outras já falecidas, escolhidas por representarem momentos de aprendizagem e comporem a caminhada de pesquisa de uma tese. Uma coleção de cartas que contavam o projeto de pesquisa da primeira autora para os membros da banca. Mas como e por que transpor esta forma de escrita para artigos e capítulos de livros? Porque acreditamos que as cartas são meios importantes para o acolhimento de ideias, conceitos e narrativas sustentados em uma lógica de abertura às questões. Produzem a abertura da linguagem, acolhem manifestações de afeto e trejeitos de escrita que costumam ser considerados inapropriados para artigos e capítulos de livros. Em uma perspectiva cartagráfica, as cartas são textos pouco preocupados com as respostas, mas sim com os percursos, com o que se constrói no entre correspondências. 
Desta forma, as cartas apontam a produção de conhecimento como um meio de acolher perguntas, que se abrem e fecham e assim nos contam de conceitos, práticas, experiências. Não seria uma tese uma coleção de perguntas? A escrita, deste modo, tem a preocupação em como ocupamos a academia e os espaços pelos quais passamos, como ocupamos os textos que produzimos. Que espaços são produzidos com cartas, caixas e sacolas? Que discussões sobre pesquisa são possíveis?

Já pensou no que ocorreria se você transformasse sua pesquisa em cartas e as compartilhasse com pessoas diversas que tenham a ver com seu tema de pesquisa? Ou que não tenham a ver com sua pesquisa? Será que surgiriam perguntas como: é ciência? É acadêmico? Teses e dissertações são aqueles materiais que veem encadernados, foi dito uma vez. Importante não fazer pouco caso de perguntas e afirmações como estas, pois corre-se o risco de se pactuar com um determinado tipo de universidade e de produção acadêmica que não é inclusivo e acessível e que não é endereçado.

Voltando ao gênero epistolar, essas são escritas que fazem vibrar a vida, que se abrem à escuta dos afetos e que permitem passagem. Importante salientar que não estamos falando de cartas burocráticas ou comerciais, mas das que eram trocadas entre parentes, amantes, amigas/os. Como as que passaram a constituir a coleção de muitas/muitos intelectuais e artistas, como Ana Cristina César, Clarice Lispector, Mário de Andrade, Walter Benjamin, entre outras/os. Portanto, o ato de escrever cartas aposta em uma escrita que amplia as possibilidades, que produz diálogo, que permite que a vida ganhe o terreno acadêmico. Como uma carta chega a sua/seu destinatária/o? Quais efeitos produzem a leitura de cartas na academia? Por conseguinte, o trabalho cartagráfico é composto pela preocupação com o meio, com o endereçar algo a alguém e com o conteúdo. Os correios, desta forma, servem ao artista postal, como meio e suporte para a criação artística, um valor agregado à pesquisa que tenha a intenção de operar por meio de cartas, pois a escrita e respectiva troca de correspondências, coloca a pesquisa em uma certa posição de imprevisibilidade, pois nunca sabemos como um correio irá se sustentar ou que rumos irá tomar.

\section{Cartas para desobedecer e para esperançar}

Eu sou hua escrava de V. Sa. administração de Capam. Ant ${ }^{\circ}$ Vieira de Couto, cazada. Desde que o Capam. lá foi adeministrar, q. me tirou da fazenda dos algodois, aonde vevia com meu marido, para ser cozinheira de sua caza, onde nella passo mto mal. A primeira hé q. ha grandes trovoadas de pancadas em hum filho nem sendo uhã criança q. lhe fez estrair sangue pella boca, em mim não poço esplicar q. sou hu colcham de pancadas, tanto q. cahy huã vez do sobrado abaccho peiada, por mezericordia de Ds. esCapei. A segunda estou eu e mais minhas parceiras por confeçar a tres annos. E huã criança minha e duas mais por batizar. Pello q. Peço a V.S. pello amor de Ds. e do seu Valimto. ponha aos olhos em mim ordinando digo mandar a Procurador que mande p. a fazda. aonde elle me tirou pa eu viver com meu marido e batizar minha filha q. De V.Sa. sua escrava Esperança Garcia. (SOUZA, E., p. 1, 2018). 
Cartas também servem para contar a história de uma época e de um grupo, como as cartas escritas por feministas terceiro-mundistas como a chicana Gloria Anzaldúa (2000), a asiáticoamericana Merle Woo (1988) e a escritora afro-americana Maya Angelou (2019), para quem as cartas são instrumentos que permitem narrar a si mesmas e a história de seus povos, das opressões vivenciadas por suas famílias, gerações de pessoas que sobreviveram ao deslocamento geográfico, imigração, desvalorização de seus trabalhos quando aportam no Norte Global. Cartas endereçadas para filhas que nunca foram geradas, como a carta escrita por Maya Angelou, na qual compreende que uma comunidade de mulheres plurais poderiam ser suas filhas e que, ao lerem histórias de sua vida, continuariam lutando.

Cartas-diaspóricas que sobrevoam décadas para chegarem em nossas mãos e nos incitam a produzirmos outras escritas dentro da universidade, questionando tudo o que é universal (leia-se branco). Como a carta de Esperança Garcia, uma escrava alfabetizada clandestinamente por padres jesuítas e que, no final do século XVIII, escreve uma carta para o Presidente da Província de São José do Piauí (ARRAES, 2017). Neste documento, que constitui uma das mais antigas cartas que revelam as desumanas condições de escravizadas/os, Esperança descreve os violentos castigos que elas e suas/seus filhas/os sofrem nas mãos do feitor e solicita que seja devolvida à Fazenda dos Algodões a fim de que pudesse batizar sua filha. Sobre a carta de Esperança, diz Sonia Rosa (2012, n. p.): "Saber ler e escrever é uma maneira de esticar, bem esticada a voz da gente, fazendo com que ela chegue a tempos e a lugares distantes, nunca antes imaginados". A carta de Esperança chega ao século XXI nos ensinando a seguir, a tentar, a esperançar. Portanto, permite o esticamento de nossas vozes. Esticar as vozes e as memórias é tarefa de grupos subalternizados. As cartas, em muitos casos, não passam de exercícios de memória e de testemunho. A memória popular, de acordo com Achillie Mbembe (2019), dificilmente conta histórias limpas e puras. Na memória dos povos colonizados encontram-se vários fragmentos de alguma coisa que se quebrou e que não poderá ser reconstituída de modo a recuperar sua unidade anterior. Para o intelectual camaronês, a chave de toda memória a serviço da emancipação é saber com que grau de perda podemos viver. A memória de povos subalternizados é uma tentativa de viver aquilo que não sobreviveu ao incêndio.

Como propõe Paul Preciado (2019), ao falar de movimentos que ensaiam rupturas epistemológicas às narrativas ocidentais, nosso entendimento é de que cartas podem redesenhar mapas cognitivos ao exporem os privilégios político-epistêmicos que têm sido preservados há anos quando o assunto é produção e, sobretudo, subalternização de conhecimento. Assim, perguntamos: que tipo de realidade política uma carta pode expor ao narrar histórias que são, aparentemente da esfera privada? Quais os desconcertos que produzimos quando o que se convencionou chamar de segredo (DESPRET, 2011) salta para o espaço público, revelando existências múltiplas, dissonantes, desalinhadas; experiências que nos ensinaram que deveriam nos envergonhar?

As cartas encerram sabedorias, relatos narrados a partir da própria experiência. Retratos que seriam privados, não fossem muitas vezes a coragem de lhes dar forma, sopros de vida. Como escreve Woo (1988), a escritura é ferramenta onde ela pode reelaborar seu passado, o 
legado emocional e espiritual que recebeu de sua mãe, que migrou para os Estados Unidos com 10 anos de idade e desde sempre realizou trabalhos subalternos, limpando, varrendo, servindo. Legado de autodesprezo de sua raça, gênero, nação. A escrita, neste caso, figuraria como possibilidade de reelaboração e criação de uma comunidade de irmãs dispostas a denunciar. Anzaldúa (2000) convoca em sua carta mulheres terceiro-mundistas a escreverem e publicizarem seus mundos e a não compactuarem com as regras da escrita acadêmica, preocupada em criar abismos com suas normatizações ou, nas palavras de Walter Mignolo (2015), que operam como patrulhas das fronteiras para não deixar passar as/os ilegais.

Cartas trazem a possibilidade de reunir emoção e razão em um único espaço textual e, como nos ensina Patrícia Hill Collins (2019a), ambas são necessárias para a busca do conhecimento. Elas trazem a possibilidade de que comunidades interpretativas (COLLINS, 2019b) das quais fazemos parte e que são anteriores ao nosso ingresso na universidade, possam figurar e serem reconhecidas como instâncias que nos auxiliaram a ser quem somos, uma vez que construímos conhecimento antes de chegarmos no universo acadêmico. Ao falar da produção de conhecimento de mulheres negras, essa autora nos traz a importância da sabedoria para a sobrevivência das/os subordinadas/os, deixando claro que conhecimento desprovido de sabedoria é adequado somente para quem tem poder. Deste modo, podemos pensar as cartas escritas por autoras feministas como recheadas de sabedoria, posto que suas vivências politizam o mundo, numa micronarrativa, recriam aspectos políticos do cotidiano, constroem outras possibilidades, informam sobre nossos mundos e as resistências que utilizamos para chegarmos até aqui. Em última instância, elas dão espaço para a heterogeneidade de pontos de vistas.

Fazendo uso das cartas enquanto performance de escrita neste artigo, as autoras escreveram sobre suas experiências com a escrita acadêmica. Cartas endereçadas para pessoas que costumeiramente não se encontrariam citadas em artigos acadêmicos, mas que em uma política de pesquisa como a cartagrafia se fazem importantes, pois um de seus alimentos são as cartas de cunho pessoal que escrevemos (ou não) ao longo da vida. O acionamento destas memórias é parte importante de uma política de pesquisa que intenta articular escrita, cuidado e experiência. Neste sentido, devemos assumir que as escritas destas cartas se caracterizam por um fazer que visa a descolonização dos saberes e dos seres e das subjetividades. Elas figuram como possibilidades de criações artísticas alternativas àquelas hegemônicas, que se propõem o exercício da autorreflexão e da crítica a partir de um voltarse para trás, refazendo a memória a partir das margens, como fazemos ao destinarmos cartas para nossas avós e mães, abrindo mão das citações, das paráfrases, das/os autoras/es.

\section{Descolonizar políticas de pesquisa: um exercício de cumplicidade subversiva}

Mais do que uma política de escrita, as cartas nos encontram problematizando nossas escolhas metodológicas de pesquisa: Como escolher/criar um método de pesquisa? Portanto, entendemos que uma escolha metodológica precisa ser coerente com as escolhas 
epistemológicas e de escrita que fazemos. Escrever cartas pessoais que acionam memórias afetivas e sustentam encontros é nossa escolha para multiplicar as fontes narrativas que costumam orientar muitas pesquisas. Cartas, tal como outras escritas menores, ajudam a desmobilizar o potencial hegemônico da escrita acadêmica, institucionalizada, por vezes, inexpressiva, sem vida, fechada em si (Zucolotto, 2014). Como produzir textos que possam cumprir sua tarefa e ainda serem afetivos, simples e intensos? Como dar língua aos afetos (ROLNIK, 2011)?

Não é fácil escrever esta carta. Começou como um poema, um longo poema. Tentei transformá-la em um ensaio, mas o resultado ficou áspero, frio. Ainda não desaprendi as tolices esotéricas e pseudo-intelectualizadas que a lavagem cerebral da escola forçou em minha escrita. Como começar novamente? Como alcançar a intimidade e imediatez que quero? De que forma? Uma carta, claro. (ANZALDÚA, 2000, p. 229).

Como alcançar essa intimidade de que fala Anzaldúa? A aproximação com os feminismos subalternos faz com que usemos nossa voz e escrita para além do treinamento acadêmico hegemônico que prima, como diz bell hooks (2019), por um tom erudito, no qual não devemos focar no pessoal. A autora, no livro "Erguer a voz", afirma que percebeu "a importância de manter uma voz na escrita que a fortalecesse para falar sobre questões de uma maneira mais ampla, quase conversacional" (HOOKS, 2019, p. 18). Para a autora, precisamos erguer nossas vozes para que temas não hegemônicos possam vir à tona e para que possamos produzir a partir de nossas experiências.

Como relata Grosfoguel (2012), nos foi imposto um modelo ocidentalizado e norte global centrado de universidade (branca, sexista, machista, masculina, elitista) que reproduz a sistemática de produção de conhecimento fundamental em um universal europeu/estadunidense. A hegemonia colonial tenta submeter as línguas que adentram no ambiente acadêmico através de normativas, com a exigência de domínio e reprodução de um linguajar colonial, além da reprodução de conceitos e autores eurocêntricos. Assim, o exercício que se coloca é o de aprender a desaprender (MIGNOLO, 2017) e com isso reaprender novas formas de nos ocuparmos de nossas pesquisas. Como desaprender um certo jeito de operarmos com metodologias cunhadas a partir da reprodução de conhecimentos do Norte Global? Nos questionamos quanto a isso, porque a cartagrafia tem inspirações em metodologias como a cartografia ${ }^{5}$ e conceitos oriundos da filosofia da diferença e autores como Walter Benjamin. Isto posto, nosso trabalho vem sendo o de operar criativamente com essas inspirações, submetendo-as a conhecimentos produzidos desde a América Latina.

Desta forma, a autora Silvia Cusicanqui (socióloga aymara e boliviana) nos ajuda, afirmando que nosso compromisso "sería crear lenguas francas, ch'ixis" ${ }^{6}$ " (2010, p. 99), apostando em um possível encontro entre línguas (guarani/português ou castelhano/aymara) criando espaços de conversa a partir de onde podemos tirar a "camisa de força" da língua culta e formal, desmontando sua pretensão autoritária de controle do nosso processo de conhecimento. Entendendo que não há um fora da colonialidade (GROSFOGUEL, 2012) nos colocamos a pensar em como subverter o que nos é dado como hegemônico para a produção de conhecimento em Psicologia. Abandonar toda e qualquer referência ou influência europeia 
talvez não seja necessário ou até mesmo possível. Mas como fazer uso dessas heranças que embasam nossas formações acadêmicas?

Suely Messeder (2020) discutindo as relações da universidade com a hegemonia e os pensamentos locais, nos alerta que os conhecimentos estrangeiros devem ser utilizados com parcimônia, para que evitemos alianças que reproduzam lógicas coloniais ou nos coloquem em armadilhas epistêmicas. Deste modo, opera-se como Silvia Cusicanqui (2010) e Ramón Grofoguel (2012) sugerem: um trabalho pelas brechas, em um exercício de criatividade, alimentado por fontes e referências bibliográficas locais e que permitam que o percurso metodológico possa ser coerente com o que epistemologicamente estamos propondo. Trabalhamos com mulheres e homens que pensam desde o lugar subalterno, que estão produzindo conhecimento a partir de suas vivências e memórias atravessadas pela violência colonial. Portanto, para pensar uma política de pesquisa e sua consequente escrita se faz necessário uma operação constante de invenção de novos modos de caminhar com a pesquisa. Modos que sejam inspirados em nosso chão, nossas vivências e memórias e que se pautem em autoras e autores que produzem desde aqui.

Um convívio criativo entre epistemologias como nos propõe Cusicanqui em entrevista à Boaventura de Souza Santos (2015), nos fazendo lembrar de Grosfoguel (2012) que trabalha com a ideia de cumplicidade subversiva que seria como "estratégias 'das brechas' ('cimarronas') de subversão político-cultural desenvolvidas do lado subalterno da diferença colonial em contexto como os das plantation" (p. 341). Cumplicidade subversiva são estratégias de resistência, não ocidentalizadas, praticadas por diferentes sujeitos subalternos que estão imersos em relações de poder hierarquizadas e desiguais (GROSFOGUEL, 2012). Agir em cumplicidade subversiva é operar a partir do reinvestimento e transformação de formas hegemônicas de conhecimento a partir de perspectivas não-eurocêntricas. Como exemplo da estratégia das brechas ou de cumplicidade subversiva, o autor cita a apropriação dos santos católicos pelos escravos negros, afirmando não se tratar de sincretismo, mas de um processo de transculturação dos santos católicos, uma descolonização na cumplicidade estabelecida com eles, subvertendo e os redefinindo a partir de uma visão de mundo diferente, não europeia. Desta forma, a cartografia, o conceito de coleção, a pesquisa-ação são inundados por referências que sustentam novas formas de se relacionar com a produção de conhecimento.

Por consequência, propomos que as cartas e a cartagrafia sejam pensadas a partir de um exercício de "cumplicidade subversiva" (GROSFOGUEL, 2012, p. 352), podendo fazer uso de referenciais estrangeiros, mas os submetendo ao nosso jogo, ao que produzimos aqui, sob influências negras, indígenas, andinas. Portanto, escrevemos cartas por acreditar que a saída para enfrentarmos a violência colonial na produção de conhecimento é apostando em políticas de pesquisa que possam olhar para o miúdo, como afirmam Simas e Rufino (2020). Uma tomada de atitude decolonial que entende que não se deve assumir uma espécie de fundamentalismo negando a produção hegemônica do Norte Global (GROSFOGUEL, 2012), mas agirmos com parcimônia com o que foi e é produzido em solo europeu e estadunidense, já que de acordo com Cusicanqui (2010) estes não podem nos servir de imediato. De acordo com a autora, o desafio que se coloca quando pensamos processos de descolonização a partir 
do continente americano é conseguirmos construir laços que rompam com os movimentos de colonialismo interno e que não sejam baseados na hierarquia global hegemônica, mas sirvam para que possamos construir nossa própria ciência. Um processo que nos coloque em diálogo com nós mesmos, em uma conversa entre países vizinhos, com teóricas/os oriundas/os de Ásia e África, para que possamos "enfrentar los proyectos hegemónicos del norte con la renovada fuerza de nuestras convicciones ancestrales" (CUSICANQUI, 2010, p. 73).

\section{Cartas: por uma produção acadêmica que enlace memória, cuidado e escrita}

Uma pista deixada por Graciela Hierro Pérezcastro, filósofa feminista mexicana nos acompanha enquanto tecemos este artigo: "Tal vez se escriban memorias para no morir del todo" ${ }^{8}$ (2000, p. 9). Ela inicia seu livro de memórias com esta afirmação, defendendo a ideia de que o conhecimento se produz a partir da reflexão sobre o vivido. A autora, como outras mulheres já citadas por nós, aponta para a necessidade de pensarmos a partir de nossas experiências, acolhendo aquilo que nos passa. Voltando à autora: "Hay que aprender a escribir con tu propia letra, vivir en el cuerpo que eres ${ }^{9 "}$ (2000, p. 12). Desta maneira, uma pesquisa cartagráfica que aciona memórias pessoais e sentimentais pauta-se por produzir rastros que marcam o corpo da universidade com a experiência. Mulheres como Gloria Anzaldúa (2000), bell hooks (2019), Maya Angelou (2019) e Graciela Pérezcastro (2000) nos ensinam que é preciso apostar nas histórias pessoais, nos vividos tão diversos ao mesmo tempo que nos contam de uma história coletiva.

A escrita de cartas, assim, aciona memórias e formas de lidar com o tempo que busquem romper com o tempo produtivista capitalista neoliberal. Estamos buscando a construção de uma academia encarnada, viva, que pulse, que acolha, cuide, produza, permita escrever/sentir/falar, sendo acolhimento para diferentes epistemologias e muitas formas de comunicar o pensamento. Desse jeito, apostamos que as cartas têm potencial para acolher uma escrita falada que flerta com a oralidade, permitindo que se escreva falando. Escritas que permitam o exercício do tateio (COSTA; AMARAL, 2017); um estar no mundo, ao modo dos autistas, como escreve Hélia Borges (2019) no livro "A clínica contemporânea e o abismo do sentido", ao afirmar que o "autista não rejeita o humano nem foge do relacionar-se [...] o que se testemunha no autista é um engajamento com o mais-que-humano, um engajamento à vida" (p. 114). Um modo de sentir, olhar, tatear, cheirar "texturas, luzes e sombras, movimentos, gradientes e transições; aquilo que se coloca fora de uma percepção linear" (p. 114). Pode a escrita dar conta dessas intensidades?

A escrita de cartas aciona uma política de pesquisa que se tece por escritas, buscando instalar estados de encantamento, entendidos "como ato de desobediência, transgressão, invenção e reconexão: armação da vida, em suma", como afirmam Luiz Antônio Simas e Luiz Rufino (2020, p. 6). Cartas, nesta relação, tomam forma de conversas lançadas ao infinito, evocando uma outra perspectiva de tempo para a pesquisa. Um tempo de histórias para adiar o fim do mundo como nos convida a pensar Ailton Krenak (2019). O autor nos faz 
pensar em como nos enlaçamos a um ideal de "humanidade zumbi que estamos convocados a integrar e que não tolera prazer e fruição de vida" $(2019$, p. 26). Sua provocação para (re)existirmos ao fantasma do fim do mundo que faz com que desistamos de nossos sonhos é "sempre poder contar mais uma história" (p. 27).

Desta forma, contar mais uma história enlaça-se com a possibilidade de esticarmos nossa voz o mais longe possível (como fizeram mulheres como Esperança Garcia e Maya Angelou, por exemplo), para que façamos furos nas políticas de desencantamento colonial ao qual estamos subordinadas. Apostar em cartas e em contar histórias é então, um exercício de vivacidade, de alimento para uma perspectiva pluriversal da produção de conhecimento na área das Ciências Humanas. Imaginem uma política de pesquisa e de escrita que nos ajudem a empurrar o céu quando sentimos que este está ficando muito baixo para podermos respirar, como afirma Ailton Krenak (2019).

Uma política de pesquisa que escolhe e acolhe as cartas enquanto suporte e forma de ser ofertada ao coletivo acadêmico precisa pensar sobre suas implicações com a arte de contar vidas e escrever narrativas, sobre a memória como esse comum que é possível de ser transmitido. Um processo que envolve principalmente a escuta e um aprender a ouvir que precisa desaprender as formas coloniais com as quais nossos ouvidos são disciplinados. Quais as histórias e memórias do miúdo nos interessam? Como nossos ouvidos acolhem essas histórias que não estão nos livros, que não são protagonistas nas salas de aula? Perguntas que acionam nossa preocupação com o aprender a contar histórias, aprender a ouvir, não apressando a escuta, quando os tempos e exigências do capitalismo colonial neoliberal nos empurram para práticas individualizadas e individualizantes.

Gostaríamos de finalizar este artigo enfatizando que políticas de escrita e de pesquisa precisam estar pautadas por exercícios de acolhimento de vozes comprometidas com a liberdade humana, como afirma Mariléa de Almeida (2019) no prefácio do livro "Erguer a Voz" de bell hooks. As cartas em nossas trajetórias surgem como escritas pelas quais podemos recuperar nossas histórias, em uma possibilidade de encontro com tempos e personagens distintos e que compõem um exercício de coletividade. Em tempos de ataques à produção do conhecimento no campo das Ciências Humanas e principalmente ataques a escolas e universidades, precisamos apostar em pesquisas que desafiem a contar nossas histórias e nossos sonhos, podendo então encontrarmos uma voz em nossas vidas (HOOKS, 2019, p. 21). Logo, nosso combate contra o individualismo a que somos empurradas pela ideologia neoliberal é carregado de memórias, histórias, cartas, envelopes e objetos que nos ajudem a resistir às políticas do desencanto.

\section{Notas}

1. Produzida por Bruna Moraes Battistelli, Carta-grafias: entre cuidado, pesquisa e acolhimento, é uma dissertação que foi defendida em 2017, sob a orientação da professora doutora Lílian Rodrigues da Cruz. (BATTISTELLI, B. M. Carta-grafias: entre cuidado, pesquisa e acolhimento. 2017. Dissertação (Mestrado em Psicologia Social e Institucional) - Instituto de Psicologia, Universidade Federal do Rio Grande do Sul, Porto Alegre, 2017. Disponível em: https://lume.ufrgs.br/handle/10183/169461. Acesso em: 20 jul. 2020.) 
2. O acolhimento institucional de crianças e adolescentes é um dos serviços de Proteção Social Especial (PSE) de Alta Complexidade do Sistema Único de Assistência Social (SUAS) e devem garantir proteção integral, com a oferta de moradia, alimentação, higienização e trabalho protegido para famílias e indivíduos que destes necessitam, a saber, a população que vive em condição de risco pessoal ou social decorrente da ocorrência de abandono, maus tratos físicos e, ou, psíquicos, abuso sexual, uso de substâncias psicoativas, cumprimento de medidas socioeducativas, situação de rua, situação de trabalho infantil, dentre outras. Fazem parte desta modalidade os Serviços de Acolhimento Institucional, os Serviços de Acolhimento em República, os Serviço de Acolhimento em Família Acolhedora e os Serviços de Proteção em situações de Calamidades Públicas e de Emergências. A instituição onde foi realizada a pesquisa caracteriza-se por ser um Serviço de Acolhimento Institucional, na modalidade de Abrigo Institucional, que funciona em espaço destinado ao atendimento de grupos de até 20 crianças e/ou adolescentes, onde são atendidos por uma equipe de profissionais, formada por técnicos e educadores sociais.

3. A produção de um artigo com cartas e sobre cartas nos faz pensar em como acolher as demandas institucionais quanto as normas de publicação (no caso ABNT), desta forma, escolhemos, por sugestão do parecer recebido do artigo em modificar a fonte das cartas ao longo do artigo. E por se tratar de um artigo escrito a partir de uma perspectiva feminista e decolonial e que busca priorizar e visibilizar a produção intelectual de mulheres subalternizadas, optamos por citar o nome completo das autoras e autores citados ao longo do texto, com exceção das citações entre parênteses. A proposta de pensarmos uma pesquisa escrita com cartas é colocar também em suspensão o que nos é solicitado pela instituição acadêmica quanto à normas de publicação.

4. Trata-se do projeto de tese intitulado Histórias que valem à pena: carta-grafias para uma política do Texto feminista em Psicologia Social da autora Bruna Moraes Battistelli (doutoranda no Programa de Pósgraduação em Psicologia Social e Institucional da UFRGS) orientada pelo professor doutor Luciano Bedin da Costa (UFRGS) e co-orientada pela professora doutora Érika Cecília Soares Oliveira (UFAL).

5. O entendimento da cartografia é inspirado na ideia de pesquisador in-mundo (Abrahão et al., 2014), que pressupõe o processo e análise de implicação do pesquisador quanto ao caminho que o levou a tal objeto de pesquisa. Não há neutralidade do sujeito-pesquisante que no processo de se colocar in-mundo, contaminase ao dar passagens para múltiplos processos de subjetivações e de fabricações de mundo, afirmam os autores.Assim, a pesquisa que visa acompanhar processos, parte do pressuposto de que todos os envolvidos são pesquisadores que constituem suas cartografias a partir dos mais diversos interesses. Inspirada na Filosofia da diferença e na obra de autores como Gilles Deleuze e Félix Guattari, se fez uma dobra operando com a cartografia desenvolvida em nossas terras, por pesquisadoras/es da área da saúde prioritariamente (Abrahão et al., 2014), como também, com autoras como Virgínia Kastrup, Laura Pozzana e Suely Rolnik. A cartografia intenciona mostrar o que é visível somente ao campo do sensível e seu interesse está na processualidade da produção dos encontros, não havendo assim interesse por um produto final. (Bertussi et al., 2011). Desta forma, os autores afirmam que cartografar é um processo que visa acompanhar linhas, intensidades que se atualizam, vivenciar.

6. Mesmo que as normas da ABNT orientem que as citações em língua estrangeira devam ser citadas traduzidas e apresentadas em sua língua original nas notas de rodapé, escolhemos fazer a inversão, em respeito às línguas originárias das autoras Silvia Cusicanqui e Graziela Pérezcastro. "Seria criar línguas francas, ch'ixis" (Tradução nossa).

7. "Enfrentar os projetos hegemônicos do norte com a renovada força de nossas convicções ancestrais" (Tradução nossa).

8. "Talvez se escrevam memórias para não morrer totalmente." (Tradução nossa).

9. “É preciso aprender a escrever com tua própria letra, viver com o teu corpo.” (Tradução nossa). 


\section{Referências bibliográficas}

ABRAHÃO, A. L. et al. O pesquisador in-mundo e o processo de produção de outras formas de investigação em saúde. In: CERQUEIRA, M. P. G.; MERHY, E. E. (org.). Pesquisadores in-mundo: um estudo da produção do acesso e barreira em saúde mental. Porto Alegre: Rede UNIDA, 2014. p. 155-170.

ALMEIDA, M. Prefácio. In: HOOKS, B. Erguer a voz: pensar como feminista, pensar como negra. São Paulo: Elefante, 2019. p. 8-15.

ANGELOU, M. Carta a minha filha. Rio de Janeiro: Agir, 2019.

ANZALDÚA, G. Falando em línguas: uma carta para as mulheres escritoras do terceiro mundo. Revista Estudos Feministas, Florianópolis, v. 8, n. 1, p. 229-236, 2000.

ARAUJO, T. C. Caixa de correio: lugar de entrada, de passagem e de acúmulo de memórias. 2016. Tese (Doutorado em Artes) - Escola de Belas Artes, Universidade Federal de Minas Gerais, Belo Horizonte, 2016.

ARRAES, J. Esperança Garcia. In: ARRAES, J. Heroínas negras brasileiras em 15 cordéis. São Paulo: Polén, 2017. p. 57-62.

BATTISTELLI, B. M. Branquitude I. In: PERONDI, M. et al. (org.). Juventudes entre A \& Z . Porto Alegre: Editora Cirkula, [2020a]. No prelo.

BATTISTELLI, B. M. Branquitude II. In: PERONDI, M. et al. (org.). Juventudes entre A \& Z. Porto Alegre: Editora Cirkula, [2020b]. No prelo.

BATTISTELLI, B. M. Carta-grafias: entre cuidado, pesquisa e acolhimento. 2017. Dissertação (Mestrado em Psicologia Social e Institucional) - Instituto de Psicologia, Universidade Federal do Rio Grande do Sul, Porto Alegre, 2017. Disponível em: 〈https://lume.ufrgs.br/handle/10183/169461 >. Acesso em: 20 jul. 2020.

BATTISTELLI, B. M.; CRUZ, L. R. Cartas à Assistência Social. In: CRUZ, L. R.; GUARESCHI, N.; BAtTISTELli, B. M. (org.). Psicologia e Assistência Social: encontros possíveis no contemporâneo. Petrópolis: Vozes, 2019a. p. 15-35.

BATTISTELLI, B. M.; CRUZ, L. R. Pesquisando com crianças em Acolhimento Institucional. In: SIQUEIRA, R. M.; SOUSA, S. M. G. (org.). Por uma luta em defesa dos direitos das crianças: instituições e cotidianos. 1. ed. Goiânia: Editora Vieira, 2019b. p. 941-952.

BERTUSSI, D.; BADUY, R. S.; FEUERWERKER, L. C. M.; MERHY, E. E. Viagem cartográfica: pelos trilhos e desvios. In: MATTOS, R. A.; BAPTISTA, T. W. F. (org.). Caminhos para análise das políticas de saúde. Porto Alegre: Rede UNIDA, 2011. p. 306-324.

BORGES, H. A clínica contemporânea e o abismo do sentido. Rio de Janeiro: 7Letras, 2019.

CARRIÓN, U. Rede Internacional de Correio Artístico Imprevisível. In: BIENAL DE SÃO PAULO, 16., 1981, São Paulo. Catálogo de arte postal. São Paulo: Bienal de São Paulo, 1981. v. 2, p. 11.

CATANiO, N.; BATtiSTElli, B. M. Cartas sobre cuidado. Alegrar. Campinas, n. 23, p. 97-108, jan./jul. 2019.

CÉSAR, A. C. Correspondência incompleta. São Paulo: Aeroplano Editora, 1999.

CÉSAR, A. C.; BOSI, V. Antigos e soltos: poemas e prosas da pasta rosa. Rio de Janeiro: Instituto Moreira Salles, 2008.

COLLINS, P. H. Epistemologia feminista negra. In: BERNARDINO-COSTA, J.; MALDONADO-TORRES, N.; GROSFOGUEL, R. (org.). Decolonialidade e pensamento afrodiaspórico. Belo Horizonte: Autêntica Editora, 2019a. p. 139-170.

COLLINS, P. H. Pensamento feminista negro e estudos da tradução: entrevista com Patrícia Hill Collins. Revista Ártemis, João Pessoa, v. 27, n. 1, p. 229-235, jan./jun., 2019 b. 
COSTA, L. B.; AMARAL, A. O improrrogável: exercícios de tateio. Revista Polis e Psique, Porto Alegre, v. 7, n. 1, p. 1-5, 2017.

CUSICANQUI, S. R. Ch'ixinakax utxiwa: una reflexión sobre prácticas y discursos descolonizadores. Buenos Aires: Tinta Limón, 2010.

CUSICANQUI, S. R.; SANTOS, B. S. Conversa del mundo. In: SANTOS, B. S. Revueltas de indignación y otras conversas. Bolivia: Proyecto ALICE, 2015. p. 80-123.

DESPRET, V. Leitura etnopsicológica do segredo. Fractal: Revista de Psicologia, Niterói, v. 23, n. 1, p. 5-28, abr. 2011. Disponível em: <http://www.scielo.br/scielo.php?script=sci_arttext\&pid=S198402922011000100002\&lng=en\&nrm=iso>. Acesso em: 20 jul. 2020.

FLUSSER, V. A escrita: há futuro para a escrita? São Paulo: Annablume, 2010.

GROSFOGUEL, R. Descolonizar as esquerdas ocidentalizadas: para além das esquerdas eurocêntricas rumo a uma esquerda transmoderna descolonial. Contemporânea: Revista de Sociologia da UFSCar, São Carlos, v. 2, n. 2, p. 337-362, 2012.

HOOKS, B. Erguer a voz: pensar como feminista, pensar como negra. São Paulo: Elefante, 2019.

KRENAK, A. Ideias para adiar o fim do mundo. São Paulo: Companhia das Letras, 2019.

MBEMBE, A. Poder vital, resistência visceral. São Paulo: n-1 Edições, 2019. (Série Pandemia). Disponível em: 〈https://n-1edicoes.org/poder-vital-resistencia-visceral >. Acesso em: 20 jun. 2020.

MERHY, E. E. O cuidado é um acontecimento e não um ato. In: FRANCO, T. B.; MERHY, E. E. (org.). Trabalho, produção do cuidado e subjetividade em saúde. São Paulo: Hucitec, 2013. p. 172-182.

MESSEDER, S. A pesquisadora encarnada: uma trajetória decolonial na construção do saber científico blasfêmico. In: HOLLANDA, H. B. (org.). Pensamento feminista hoje: perspectivas decoloniais. Rio de Janeiro: Bazar do Tempo, 2020. p. 154-171.

MIGNOLO, W. Desafios decoloniais hoje. Revista Epistemologias do Sul, Foz do Iguaçu, v. 1, n. 1, p. 12-32, 2017.

MIGNOLO, W. Habitar la frontera: sentir y pensar la descolonialidad. Antología, 1999-2014. Barcelona: Edicions Bellaterra, 2015.

OLIVEIRA, E. C. S. Manifesto Antirracista: carta a Sara Baartman. In: GOULART, P. M.; PEZZATO, L. M. (org.). Narrativas de si: práticas em educação e saúde. 1. ed. Porto Alegre: Rede UNIDA, 2020. p. 149160.

PÉREZCASTRO, G. H. Gracias a la vida. México: DEMAC, 2000.

PRECIADO, P. B. Un apartamento en Urano: crónicas del cruce. Barcelona: Editorial Anagrama, 2019.

RODRIGUES, L.; BATTISTELLI, B. Entre cartas: sobre branquitude e epistemicídio na produção de conhecimento em Psicologia. In: SILVEIRA, R. S.; SILVA, L. G.; NARDI, H. C.; RODRIGUES, L. (org.). Psicologia e relações raciais: um percurso em construção. Porto Alegre: Gráfica da UFRGS, [2020]. p. 4364. No prelo.

RODRIGUES, S. Cartas Brasileiras: correspondências históricas, políticas, célebres, hilárias e inesquecíveis que marcaram o país. São Paulo: Companhia das Letras, 2017.

ROLNIK, S. Cartografia sentimental. Porto Alegre: Editora da UFRGS, 2011.

ROLNIK, S. Esferas da insurreição: notas para uma vida não cafetinada. São Paulo: n-1 Edições, 2018.

ROSA, S. Quando a escrava Esperança Garcia escreveu uma carta. Rio de Janeiro: Pallas, 2012. Não paginado.

SCHEDLER, L. Arte (Postal) como processo. Palíndromo, Florianópolis, v. 8, n. 15, p. 20-41, 2016.

SIMAS, L. A.; RUFINO, L. Encantamento (sobre política de vida). Rio de Janeiro: Mórula Editorial, 2020. E-book. 
SOUZA, E. F. A carta da escrava 'Esperança Garcia' de Nazaré do Piauí: uma narrativa de testemunho precursora da literatura afro-brasileira. Literafro, Belo Horizonte, 9 fev. 2018. Críticas. Disponível em: <http://www.letras.ufmg.br/literafro/arquivos/artigos/criticas/ArtigoElioferreiralcartaesperancagarcia.pdf $>$. Acesso em: 20 jul. 2020.

SOUZA, L. G. B. Arte Postal: perspectivas de uma arte em rede. 2010. Dissertação (Mestrado em Comunicação) - Universidade Federal de Pernambuco, Recife, 2010.

WOO, M. Carta a amá. In: MORAGA, C.; CASTILLO, A. Esta puente, mi espalda: voces de mujeres terceromundistas en los Estados Unidos. San Francisco: Ism Press, 1988. p. 109-120.

ZUCOLOTTO, M. P. R. A Escrita em Transversal: tempo, errância e experimentações no escrever. 2014. Tese (Doutorado em Psicologia Social) - Departamento de Psicologia Social e Institucional, Instituto de Psicologia, Universidade Federal do Rio Grande do Sul, Porto Alegre, 2014.

\section{Correspondência}

Bruna Moraes Battistelli: Graduada em Psicologia pela Universidade Federal do Rio Grande do Sul (UFRGS), especialista em Instituições em Análise (UFRGS), mestra em Psicologia Social e Institucional (UFRGS) e doutoranda no Programa de Pós-graduação em Psicologia Social e Institucional (UFRGS). Bolsista CAPES. O presente trabalho foi realizado com apoio da Coordenação de Aperfeiçoamento de Pessoal de Nível Superior - Brasil (CAPES) - Código 001.

E-mail: brunabattistelli@gmail.com

Érika Cecília Soares Oliveira: Graduada em Psicologia pela Universidade Estadual Paulista (UNESP), Mestra em Educação para a Ciência (UNESP) e Doutora em Psicologia (UNESP). Atualmente é professora do Departamento de Fundamentos Pedagógicos da Universidade Federal Fluminense trabalhando com os seguintes temas: epistemologias do sul, feminismos subalternos, decolonialidade, políticas de escrita.

E-mail: erikaoliveira@id.uff.br

Texto publicado em Currículo sem Fronteiras com autorização dos autores. 